ArtikelPenelitian

\title{
Hubungan Riwayat Pola Pemberian ASI Eksklusif dengan Perkembangan Anak PraSekolah di Kecamatan Koto Tangah Kota Padang
}

\author{
Nurul Aini ${ }^{1}$, Eva Chundrayetti ${ }^{2}$, Rika Susanti ${ }^{3}$
}

\begin{abstract}
Abstrak
Pemberian ASI ekslusif sebagai makanan terbaik untuk bayi di enam bulan pertama kehidupan belum dilaksanakan dengan baik. Hal ini disebabkan berbagai factor baik internal maupun eksternal. Hal ini di tunjukkan dengan cakupan ASI eksklusif yang belum mencapai target. Tujuan penelitian ini adalah menentukan hubungan riwayat pola pemberian ASI eksklusif dengan perkembangan anak prasekolah. Metode penelitian ini menggunakan survey analitik cross sectional, dilaksanakan dari Februari 2016 sampai Januari 2017 di Kecamatan Koto Tangah Kota Padang. Pengambilan sampel dengan teknik purposive sampling, sehingga didapatkan 110 anak prasekolah berusia 4-6 tahun. Pengumpulan data menggunakan kuesioner ASI dan Kuesioner Pra Skrining Perkembangan (KPSP). Hasil penelitian menunjukkan dari 110 sampel didapatkan 43 anak prasekolah yang mendapatkan ASI eksklusif, diperoleh perkembangan yang sesuai usia sejumlah 37 anak (86,0\%) sedangkan 5 anak (11,6\%) meragukan dan penyimpangan sebesar 1 anak (2,3\%). Dari 67 anak prasekolah yang tidak ASI eksklusif, ada sebanyak 40 anak (59,7\%) anak dengan perkembangan sesuai usianya , 23 anak (34,3\%) meragukan dan 4 anak (6\%) mengalami penyimpangan. Hasil uji analisis chisquare diperoleh nilai $p=0.013(p<0.05)$, Simpulan studi ini adalah ada hubungan yang signifikan antara riwayat pemberian ASI eksklusif dengan perkembangan anak prasekolah.
\end{abstract}

Kata kunci: ASI eksklusif, perkembangan, Anak Prasekolah

\section{Abstract}

Exclusive breastfeeding is the best food for baby in the first 6 month of life and it isn't done properly. This is caused by various internal and external factors. This is showed by small scope of exclusive breastfeeding coverage and does not meet the target. The objective of this study was to determine the relation history of exclusive breastfeeding pattern on pre-school child development. This Research using cross sectional analytic survey method with cross sectional approach, held in February 2016 and January 2017 in the sub-district Koto Tangah Padang Province of West Sumatra. Using the technique of $f$ sampling purposive sampling, with the number of sample 110 children pre-school aged 4-6 years. The collection of data with the use of the questionnaire breast milk and the Questionnaire Pre Screening Development (KPSP). The results from 110 samples demonstrate that 43 children preschool who get exclusive breastfeeding, 37 children (86.0\%) have their developments correspond with developmental milestone, whereas 5 children (11.6\%) doubts and deviation of 1 children (2.3\%). From 67 children pre-school which is not exclusive breastfeeding, there are as many as 40 children (59.7\%) children with the development of the appropriate age, 23 children (34.3\%) that doubt and 4 children (6\%) experiencing deviations. Test results obtained Chi square analysis the value of $p=0.013(p<0.05)$ it is concluded there is significant correlation between exclusive breastfeeding history with preschool children development.

Keywords: exclusive breast feeding, development, pre school children 
Affiliasi penulis: 1. Prodi Profesi Dokter FK Unand (Fakultas Kedokteran Universitas Andalas Padang), 2. Bagian IImu Kesehatan Anak FK Unand/RSUP Dr.M.Djamil, 3. Bagian Forensik FK Unand/RSUP.Dr.M.Djamil.

Korespondensi: Nurul Aini, Email : nurulaini5995@gmail.com,Telp: 085272079697

\section{PENDAHULUAN}

ASI merupakan nutrisi terbaik dan terpenting untuk mencapai tumbuh kembang yang optimal seorang anak, World Health Organization (WHO) merekomendasikan pemberian ASI sebaiknya paling sedikit selama enam bulan pertama atau disebut juga dengan ASI eksklusif, kemudian dilanjutkan dengan Makanan Pendamping (MP) ASI sampai usia dua tahun. ${ }^{1}$

WHO menargetkan cakupan ASI eksklusif pada tahun 2015 sebanyak minimal 50\%. ${ }^{1}$ Pada Keputusan Menteri Kesehatan Nomor 450/MENKES/SK/VI/2014 tentang pemberian ASI eklusif di Indonesia diberikan selama enam bulan dan dianjurkan untuk melanjutkan sampai usia anak dua tahun atau lebih, dengan didampingi pemberian makanan tambahan yang sesuai, kemudian Kemenkes juga menghimbau agar tenaga kesehatan menginformasikan kepada semua ibu yang baru melahirkan untuk memberikan $\mathrm{ASI}^{2}$

Manfaat ASI sudah tidak diragukan lagi, dari beberapa penelitian yang pernah dilakukan terlihat anak yang mendapat ASI jauh lebih matang, lebih asertif dan memperlihatkan progresifitas yang lebih baik pada skala perkembangan dibanding mereka yang tidak mendapat $\mathrm{ASI}^{3}$

Pada saat ini pemberian ASI ekslusif sebagai makanan terbaik untuk bayi di enam bulan pertama kehidupan belum dilaksanakan dengan baik. Hal ini disebabkan berbagai faktor baik internal maupun eksternal. Faktor internal berasal dari ibu seperti kurangnya pengetahuan ibu, kondisi kesehatan ibu, dan status pekerjaan ibu. Contoh faktor eksternal ialah kurangnya dukungan orang terdekat, fasilitas pelayanan kesehatan, dan masih adanya pengaruh dari promosi produsen susu formula dan makanan atau minuman bayi yang lain. ${ }^{4}$

Data Dinas Kesehatan Provinsi Sumatra Barat indikator pemberian ASI eksklusif mengalami kenaikan tiap tahunya namun belum mencapai target pada tahun 2015 ialah sebesar 83,00 \% sedangkan di Kota
Padang sendiri $70,5 \%$ belum mencapai angka nasional provinsi maupun target provinsi.$^{5}$ Diketahui juga bahwa cakupan pemberian ASI eksklusif tertinggi di kota Padang terdapat di Kecamatan Padang Utara terutama pada Puskesmas Alai yakni sebesar 90,63\% sedangkan terendah terdapat pada Kecamatan Koto Tangah terutama pada Puskesmas Air Dingin yakni sebesar $52,57 \%{ }^{6}$

Masa lima tahun pertama merupakan masa yang sangat peka terhadap lingkungan, maka disebut juga "Golden Period", "Window of Opportunity" dan "Critical Period" 7. Masa balita digolongkan juga dengan masa prasekolah yang terjadi mulai akhir masa bayi (24 bulan - 72 bulan ) atau 2 - 6 tahun. Pada masa ini pertumbuhan dasar akan mempengaruhi dan menentukan perkembangan anak selanjutnya. $^{8}$ Proses tersebut berlansung dengan sangat pesat dan dipengaruhi oleh lingkungan namun, berlangsung sangat pendek dan tidak dapat diulangi lagi, sehingga disebut sebagai masa keemasan (golden periode). ${ }^{9}$

Penelitian yang memantau pertumbuhan dan perkembangan bayi yang mendapat ASI eksklusif telah banyak dikerjakan di negara maju. Hasil penelitian mendapatkan bahwa pertumbuhan bayi dengan berat badan lahir cukup yang mendapatkan ASI eksklusif sesuai dengan standar pertumbuhan menurut World Health Organization- National Care for Health(WHO-NHCS). ${ }^{10}$ Hasil penelitian di Indonesia didapatkan bahwa anak yang tidak mendapatkan ASI eksklusif mempunyai perkembangan kognitif lebih rendah dibanding anak normal lainnya. Tujuan dari penelitian ini ialah untuk mengetahui hubungan riwayat pola pemberian ASI eksklusif dengan perkembangan anak pra sekolah.

\section{METODE}

Penelitian dimulai dari pembuatan proposal kemudian dilanjutkan dengan pengambilan data di Dinas Kesehatan dan Dinas Pendidikan Kota Padang, kemudian dilakukan penelitian di 2 Taman Kanakkanak (TK) di Kecamatan Koto Tangah untuk mewakili daerah tersebut yang dilakukan dipada bulan November 2016 hingga Januari 2017. Jenis penelitian yang digunakan dalam penelitian ini adalah analitik untuk mengetahui hubungan pemberian ASI eksklusif 
terhadap perkembangan anak pra sekolah di Kecamatan Koto Tangah. Desain yang digunakan adalah cross sectional dimana variabel-variabel diobservasi pada waktu yang sama. ${ }^{12}$ Sampel minimal dalam penelitian ini adalah sebesar 106 orang, namun dilapangan didapatkan total responden 110 orang.

\section{HASIL}

Tabel 1. Hubungan pemberian ASI eksklusif dengan perkembangan anak pra sekolah

\begin{tabular}{|c|c|c|c|c|c|c|}
\hline \multirow{3}{*}{ ASI } & \multicolumn{5}{|c|}{ Perkembangan } & \multirow[b]{3}{*}{$\%$} \\
\hline & \multicolumn{2}{|c|}{ Sesuai } & \multicolumn{2}{|c|}{ Meragukan } & $\begin{array}{l}\text { Penyim- } \\
\text { pangan }\end{array}$ & \\
\hline & $f$ & $\%$ & $f$ & $\%$ & f $\%$ & \\
\hline Eksklusif & 37 & 86,0 & 5 & 11,6 & 12,3 & \\
\hline $\begin{array}{l}\text { Tidak } \\
\text { Eksklusif }\end{array}$ & 40 & 59,7 & 23 & 34,3 & $4 \quad 6,0$ & 0.013 \\
\hline Total & 77 & 70,0 & 28 & 25,5 & $5 \quad 4,5$ & \\
\hline
\end{tabular}

Berdasarkan Tabel 1, dari 43 anak pra sekolah yang mendapatkan ASI eksklusif, diperoleh perkembangan yang sesuai dengan perkembangannya berjumlah 37 anak $(86,0 \%)$ sedangkan 5 anak (11,6\%) meragukan dan penyimpangan sebesar 1 anak (2,3\%). Dari 67 anak pra sekolah yang tidak ASI eksklusif, ada sebanyak 40 anak $(59,7 \%)$ anak dengan perkembangan yang sesuai, 23 anak $(34,3 \%)$ yang meragukan dan 4 anak (6\%) mengalami penyimpangan. Hasil uji analisis chisquare diperoleh nilai $p=0.013(p<0.05)$ maka dapat disimpulkan ada hubungan yang signifikan antara riwayat pemberian ASI eksklusif dengan perkembangan anak pra sekolah.

\section{PEMBAHASAN}

Penelitian ini dilaksanakan di Taman Kanakkanak (TK) yang berada di Kecamatan Koto Tangah Kota Padang. Dari 73 TK yang berada di kecamatan tersebut diambil 2 TK yang mewakili populasi Kecamatan Koto Tangah yaitu TK Lillah dan, TK Mutiara Ananda. Responden penelitian ini adalah ibu dan anak prasekolah yang berusia 4-6 tahun yang berjumlah 130 orang, kemudian di dapatkan 110 responden yang memenuhi kriteria inklusi sedangkan 20 responden lain termasuk kriteria eksklusi .
Hasil penelitian didapat bahwa umur ibu terbanyak usia $30-39$ tahun $(80,9 \%)$ kemudian tingkat pendidikan terakhir ibu yang terbanyak adalah perguruan tinggi, yaitu sebanyak 71 orang $(64,5 \%)$. Pada penelitian ini ibu lebih banyak bekerja dari pada tidak bekerja, berjumlah 59 orang (53,6\%). Penelitian lain yang dilakukan oleh Kesuma juga menunjukkan bahwa responden ibu terbanyak berada pada rentang usia 20-30 tahun dengan persentase $57.9 \% .^{13} \mathrm{Hal}$ ini disebabkan pada usia tersebut merupakan usia reproduktif untuk hamil dan melahirkan, dimana pada usia tersebut alat reproduksi wanita telah berkembang dan berfungsi secara maksimal ${ }^{14}$.Penelitian yang dilakukan Ariani menyebutkan bahwa sebagian besar pendidikan terakhir ibu adalah setingkat diploma/sarjana sebesar $(63,8 \%){ }^{15}$

Distribusi frekuensi pemberian ASI eksklusif pada anak prasekolah sebanyak 43 orang (39.1\%) dan tidak ASI eksklusif sebanyak 67 orang (60.9\%) sedangkan tidak ASI ditemukan tidak ada sama sekali (0\%). Penelitian oleh Okawary tentang status pekerjaan ibu dengan pemberian ASI eksklusif, menemukan bahwa rata-rata ibu adalah ibu rumah tangga dan memliki hubungan terhadap pemberian ASI eksklusif dengan nilai signifikasi $p=0.000<0.05 .{ }^{16}$ Pekerjaan dan pendidikan terakhir orang tua memiliki kontribusi yang besar dalam praktek pemberian ASI eksklusif, dimana ibu yang tidak bekerja cendrung lebih banyak memberikan ASI eksklusif disbanding ibu yang bekerja.

Distribusi frekuensi perkembangan anak prasekolah terbanyak adalah sesuai dengan perkembangan, yaitu sebanyak 77 orang (70.\%). Penelitian ini sebanding dengan hasil penelitian Ariani di TK dan PAUD di Kecamatan Klojen Kota Malang tahun 2010 bahwa perkembangan anak normal sesuai umur adalah sebanyak 95,1 \% dan selebihnya meragukan 4,9\%. ${ }^{15} \mathrm{Di}$ Indonesia sendiri data mengenai perkembangan anak prasekolah belum terdata secara akurat dan spesifik, beberapa penelitian di Indonesia mendeteksi gangguan perkembangan anak usia prasekolah $12.8 \%-28.5 \%{ }^{17}$ Hal ini disebabkan karena faktor-faktor yang mempengaruhi perkembangan tidak hanya dari segi nutrisi tapi juga dipengaruhi oleh stimulasi dini, factor lingkungan dan social budaya setempat. 
Hubungan pemberian ASI eksklusif dengan perkembangan anak prasekolah menurut umur diketahui melalui uji chi-square. Hasil analisis menunjukkan bahwa anak yang memiliki riwayat ASI eksklusif jika dibandingkan dengan anak yang tidak memiliki riwayat $\mathrm{ASI}$ ekslusif terdapat perbedaan yang bermakna pada perkembangan menggunakan KPSP menurut umur dengan nilai $p=0.013 \quad(p<0.05)$, sedangkan anak yang tidak memiliki riwayat ASI eksklusif didapatkan persentase perkembangan sesuai sebesar 59,7 \%, meragukan $34,3 \%$ dan penyimpangan $6,0 \%$. Anak yang memiliki ASI eksklusif didapatkan persentase perkembangan sesuai $86 \%$ meragukan $11,6 \%$ dan penyimpangan $2,3 \%$. Hal ini menunjukkan bahwa perkembang anak yang memiliki riwayat ASI eksklusif masih lebih baik daripada yang tidak ASI eksklusif.

\section{SIMPULAN}

Terdapat hubungan yang bermakna antara riwayat pemberian ASI eksklusif dengan perkembangan anak pra sekolah.

\section{DAFTAR PUSTAKA}

1. WHO. World health statistics Global nutrition targets 2025 (diunduh Februari 2017). Tersedia dari: URL: HYPERLINK http://www.who.int/ nutrition/global-target-2025/en/

2. Pusat Data dan Informasi Kementrian Kesehatan RI. Tentang situasi dan analisis ASI ekslusif. Pekan ASI Internasional. Jakarta; 2014.

3. IDAI. Mengenal keterlambatan umum pada anak. 2013 (diunduh Februari 2017). Tersedia dari: URL: HYPERLINK http://www.idai.or.id/artikelseputarkesehatan-anak/Mengenal-keterlambatan perkembanganumum-padaanak

4. Peraturan Pemerintah Republik Indonesia nomor 33 Tahun 2012 tentang Pemberian Air Susu Ibu Eksklusif, Jakarta; 2012.

5. Dinas Kesehatan Provinsi Sumatra Barat. Cakupan ASI ekslusif Provinsi Sumatra Barat; 2015.

6. Dinas Kesehatan Kota Padang. Cakupan ASI ekslusif kota Padang; 2015.

7. Departemen Kesehatan Republik Indonesia tentang pemberian ASI ekslusif di Indonesia [serial online] .2007, (diunduh Februari 2016). Tersedia dari: URL: HYPERLINK http://www.depkes. go.id/resources/download/pusdatin/profilkesehatan-indonesia/profil-kesehatan-indonesia2007.pdf

8. Hidayat A. Pengantar ilmu keperawatan anak 1. Jakarta: Salemba Medika; 2005.

9. Departemen Kesehatan Republik Indonesia. tentang perkembangan anak dan program buku KIA. 2010 (diunduh Maret 2016). Tersedia dari: URL: HYPERLINK http://kesga.kemkes.go.id/ images/pedoman/BUKU\%20KIA\%202016.pdf

10. WHO. The NCHS reference and the growth of breast and bottle fed infant. 2015 (diunduh Februari 2017). Tersedia dari URL:http://www.who.int/childgrowth/publications/br eastandbottlefed/en/

11. Warsito, Raditiyo M, Eva D. Relationship between nutrition status, psychososial stimulation, and cognitive deelopment in preschool children in Indonesia . Nutrition Research and Practice (Nutr Res Pract) Bogor: Institut Pertanian Bogor Journal. 2012;5(6):451-7.

12. Sastroasmoro S. Pemilihan Subyek Penelitian dan Desain Penelitian. Jakarta: Sagung Seto; 2010.

13. Kesuma AN. Hubungan status gizi bayi dengan pemberian asi eksklusif, tingkat pendidikan ibu, dan status ekonomi keluarga di wilayah kerja Puskesmas Padang Pasir. Padang: Fakultas Kedokteran Universitas Andalas; 2013.

14. Soetjiningsih. Tumbuh kembang anak. Jakarta: EGC; 2015.

15. Ariani. Usia anak dan pendidikan ibu sebagai faktor resiko gangguan perkembangan anak. Jurnal Kedokteran Brawijaya. 2012;27(2):123-4.

16. Okawary. Hubungan status pekerjaan ibu dengan pemberian asi eeksklusif diwilayah kerja Puskesmas Seyegan Sleman Yogyakarta. Yogyakarta: Program Studi IImu Keperawatan Sekolah Tinggi IImu Kesehatan 'Aisyiyah Yogyakarta; 2015.

17. Sinto R. Penapisan perkembangan anak usia 6 bulan - 3 tahun dengan uji tapis perkembangan Denver II. Jakarta: Departemen IImu Kesehatan Anak. FKUI-RSCM. Sari Pediatri,2008;9(5):21-3. 